\title{
Biological monitoring of workers exposed to cobalt metal, salt, oxides, and hard metal dust
}

\author{
D Lison, J-P Buchet, B Swennen, J Molders, R Lauwerys
}

\begin{abstract}
Objective-The aim was to examine the relation between environmental and biological (blood and urine) indices of exposure to different chemical forms of cobalt. Methods-A cross sectional study was undertaken in workers exposed to cobalt metal, oxides, and salts in a refinery and to a mixture of cobalt and tungsten carbide in a hard metal producing plant.

Results and conclusion-Although biological monitoring of workers exposed to cobalt oxides showed higher blood and urine concentrations than in nonexposed subjects, these indices poorly reflected the recent exposure level. By contrast, when exposure was to soluble cobalt compounds (metal, salts, and hard metals), the measurement of urine or blood cobalt at the end of the workweek could be recommended for the assessment of recent exposure. An eight hour exposure to 20 or $50 \mu \mathrm{g} / \mathrm{m}^{3}$ of a soluble form of cobalt would lead to an average concentration in a postshift urine sample collected at the end of the workweek of 18.2 or $32.4 \mu \mathrm{g}$ of cobalt/g creatinine, respectively.
\end{abstract}

(Occup Environ Med 1994;51:447-450)

In several occupational settings (for example, in cobalt refineries), workers may be exposed to pure cobalt metal, oxides, or salts, or to mixed dusts containing cobalt in association with other substances such as metallic carbides (for instance, in the hard metal industry). Exposure is mainly by inhalation and to a certain extent by mouth. Limited quantitative data are available on the absorption of cobalt by the lung and the gastrointestinal tract in humans. It has been estimated from animal studies that the oral absorption rate can vary from $5 \%$ to $45 \%$ and that only $30 \%$ of cobalt inhaled (as cobalt oxide) is absorbed through the lung. Whatever the exposure route, cobalt is mainly excreted in urine and to a lesser extent via the faeces. The urinary elimination is characterised by a rapid phase of a few days duration followed by a second phase which may last two years or more. ${ }^{1}$ Several recent studies have shown that the determination of cobalt in blood and urine can be used as an indicator of exposure. ${ }^{2-9}$ The present study was undertaken to assess the influence of the chemical form of cobalt on the response of these biological indicators. For this purpose, environmental exposure to cobalt and its concentrations in blood and urine were characterised in workers exposed to cobalt metal, oxides, and salts in a refinery and to a mixture of cobalt and tungsten carbide in a hard metal producing plant. This paper summarises the main findings derived from the comparison of these groups.

\section{Material and methods STUDY POPULATIONS}

One hundred and twenty two male workers from a cobalt refinery and 10 workers from a cemented tungsten carbide factory were included in this study. The cobalt plant uses a wide variety of raw materials, which are first dissolved in acid. The cobalt solution is then subjected to varying hydrometallurgical purification steps and cobalt salts, oxides, and metal powders are obtained as final products. Several steps involve the manipulation of powdered materials that generate dust. Only workers whose job activities were the same throughout the study week were included in the protocol. The workers were subdivided into three groups according to their main workplace or activity. Thirty five workers were exposed to cobalt metal, 72 to cobalt salts, and 15 to cobalt oxides.

In the cemented tungsten carbide factory the work involves either the grinding of cobalt and tungsten carbide powders after the addition of paraffin, the pressing and presintering of small blocks of the mixture, and shaping and sintering at $1500^{\circ} \mathrm{C}$ in the absence of oxygen. The material is eventually blasted, brazed, and grounded under wet or dry conditions to obtain the finished hard metal tools.

Each worker was examined at the beginning (Monday) and at the end (Friday) of a workweek.

\section{AIR SAMPLING AND ANALYSIS}

For assessment of total exposure to airborne cobalt each worker was equipped with a personal dust sampler on Monday and Friday. In the refinery plant, a CIP10 dust sampler (MSA, Saint-Ouen-L'Aumône, France) equipped with a 45 and a 60 grade polyurethane foam filter was used. Air was sampled for six hours. In the hard metal plant an SKC portable pump (Dorset, UK) equipped with an open filter holder and a $0.8 \mu \mathrm{m}$ cellulose ester filter was used. Air was sampled for six to seven hours.

The cobalt content of the filter was determined by flameless atomic absorption 
Table 1 Characteristics, exposure conditions, and biological indices in the four groups of cobalt workers

\begin{tabular}{|c|c|c|c|c|}
\hline & $\operatorname{Metal}(n=35)$ & Salts $(n=72)$ & Oxides $(n=15)$ & Hard metals $(n=10)$ \\
\hline $\begin{array}{l}\text { Age } \\
\text { Exposure }(y)^{\star} \\
\text { Pack-years } \\
\text { Monday Co-air } \\
\left(\mu \mathrm{g} / \mathrm{m}^{3}\right) \dagger\end{array}$ & $\begin{array}{c}32(21-54) \mathrm{ab} \\
5 \cdot 9(0 \cdot 48-32 \cdot 4) \mathrm{a} \\
8 \cdot 0(1 \cdot 3-72 \cdot 1) \mathrm{a} \\
433(13-6819) \mathrm{a}\end{array}$ & $\begin{array}{c}28(19-55) \mathrm{a} \\
4.6(0 \cdot 31-33 \cdot 3) \mathrm{a} \\
6 \cdot 2(0 \cdot 6-77 \cdot 9) \mathrm{a} \\
68(2-7700) \mathrm{b}\end{array}$ & $\begin{array}{c}31(21-55) \mathrm{a} \\
7 \cdot 1(2 \cdot 9-22 \cdot 1) \mathrm{a} \\
11 \cdot 7(2 \cdot 6-65 \cdot 8) \mathrm{a} \\
210(5-3652) \mathrm{ab}\end{array}$ & $\begin{array}{l}45(27-52) \mathrm{b} \\
23 \cdot 0(10-32) \mathrm{b} \\
8 \cdot 0(0-60 \cdot 0) \mathrm{a} \\
9(2-127) \mathrm{c}\end{array}$ \\
\hline $\begin{array}{l}\left(\mu \mathrm{g} / \mathrm{m}^{3}\right) \top \\
\text { Monday Co-U } \\
(\mu \mathrm{g} / \mathrm{g} \text { creatinine }) \dagger\end{array}$ & $174 \cdot 7(15 \cdot 7-2244 \cdot 0) a$ & $32 \cdot 2(0 \cdot 8-1000) b c$ & $61 \cdot 6(21 \cdot 3-491 \cdot 2) \mathrm{ac}$ & $13 \cdot 1(3 \cdot 1-87 \cdot 5) b c$ \\
\hline $\begin{array}{l}\text { Monday Co-B } \\
(\mu \mathrm{g} / \mathrm{dl}) \dagger\end{array}$ & $2 \cdot 3(0 \cdot 2-16 \cdot 0) a$ & $0 \cdot 8(0 \cdot 2-12 \cdot 0) \mathrm{b}$ & $1.8(0.4-7 \cdot 7) a$ & ND \\
\hline $\begin{array}{c}\text { Friday Co-air } \\
\left(\mu \mathrm{g} / \mathrm{m}^{3}\right) \dagger\end{array}$ & $383(17-10767) a$ & $89(1-4690) b$ & $467(23-7772) a$ & $19(1-203) b$ \\
\hline $\begin{array}{l}\text { Friday Co-U } \\
(\mu \mathrm{g} / \mathrm{g} \text { creatinine })+\end{array}$ & $161 \cdot 6(13 \cdot 1-1534 \cdot 0) a$ & $45 \cdot 6(1 \cdot 6-666 \cdot 1) b$ & $70.0(13.5-2037 \cdot 5) \mathrm{ab}$ & $17 \cdot 6(3 \cdot 0-85 \cdot 6) b$ \\
\hline $\begin{array}{c}\text { Friday Co-B } \\
(\mu \mathrm{g} / \mathrm{dl}) \dagger\end{array}$ & $2 \cdot 8(0 \cdot 2-19 \cdot 0) a$ & $0.9(0.2-10.0) b$ & $1.9(0.7-7.6) a$ & ND \\
\hline
\end{tabular}

Groups with the same letter(s) are not statistically different $(p>0.05)$. ${ }^{\star}$ Median (range); + geometric mean (range). Co-U $=$ postshift cobalt in urine; Co-B = postshift cobalt in blood; Co-Air = time weighted average airborne cobalt concentration; ND $=$ not determined.

spectrometry (Perkin Elmer, Zeeman 5000) after dissolution in a $10 \%$ sulphuric acid and $1 \%$ nitric acid solution. We have verified that both sampling systems are equivalent for low and for high cobalt particle concentrations.

\section{URINE AND BLOOD ANALYSES}

In both groups a spot urine sample was collected at the end of the shift both on Monday and on Friday. Blood samples were only available from the cobalt refinery workers (postshift on both Monday and Friday). Blood and urinary cobalt concentrations were determined by flameless atomic absorption spectrometry. ${ }^{10}$ The proficiency in determining cobalt in urine was checked by the addition in each measurement series of three certified urine standards (Behring, Marburg, Germany). The accuracy and the precision of the method for urine ( $\mathrm{n}=10$ determinations) were $76.8 \%$ and $14.9 \%, 91.5 \%$ and $6.8 \%$ and $92.4 \%$ and $7.9 \%$ at target values of 5.25 , $30 \cdot 7$, and $158 \cdot 1 \mu \mathrm{g}$ of cobalt $/$, respectively. The accuracy and precision of the method for blood ( $\mathrm{n}=10$ determinations) were $97 \%$ and $3.5 \%$, and $95 \%$ and $1.0 \%$, at target values of 10 and $20 \mu \mathrm{g}$ of cobalt $/ 100 \mathrm{ml}$, respectively. Urinary creatinine concentration was measured according to the Jaffé picrate method with the use of a Technicon RA1000 automate (Tarrytown, NY, USA).

\section{STATISTICAL METHODS}

Statistical analyses were by SAS procedures (SAS Institute). When variables were not normally distributed, the analysis was performed on $\log$ transformed data or on the rank of the values. Comparisons of the means between the groups were performed by analysis of variance followed by a Duncan multiple comparison test. A simple linear regression model was used for characterisation of the relation between environmental and biological measurements. A $\mathrm{p}$ value $<5 \%$ was considered as the level of statistical significance.

\section{Results}

Table 1 summarises the characteristics and exposure conditions of the different groups. No significant difference in the smoking habits was noticed between the groups. The mean age and exposure duration were not significantly different except in hard metal workers who were older and exposed for a longer time than the other groups. The salt and hard metal groups were significantly less exposed to cobalt than the metal and oxide groups. As mentioned, blood samples were not available from hard metal workers. The average blood and urine values in the different groups were notably higher than in nonexposed subjects in whom they were usually below $2 \mu \mathrm{g} / \mathrm{g}$ creatinine for urine and $0.2 \mu \mathrm{g} / \mathrm{dl}$ for blood. A notable discrepancy was found between the cobalt metal and oxide groups. Although airborne cobalt concentrations were similar in the oxide and in the metal groups, the average cobalt concentrations in urine and in blood were lower in the oxide than in the

Table 2 Relations between cobalt concentrations in workplace air, urine, and blood

\begin{tabular}{|c|c|c|c|c|c|c|c|c|c|c|c|c|}
\hline & \multicolumn{12}{|c|}{ Log Co-air } \\
\hline & \multicolumn{3}{|c|}{ Metal $(n=35)$} & \multicolumn{3}{|c|}{ Salts $(n=72)$} & \multicolumn{3}{|c|}{ Oxides $(n=15)$} & \multicolumn{3}{|c|}{ Hard metals $(n=10)$} \\
\hline & $r$ & $b$ & p Value & $r$ & $b$ & p Value & $r$ & $b$ & p Value & $r$ & $b$ & p Value \\
\hline $\begin{array}{l}\log (C o-U) \\
\text { Monday endshift } \\
\text { ME-MM } \\
\text { Friday endshift } \\
\text { FE-FM }\end{array}$ & $\begin{array}{l}0.79 \\
0.72 \\
0.57 \\
0.63\end{array}$ & $\begin{array}{l}0.59 \\
0.69 \\
0.43 \\
0.55\end{array}$ & $\begin{array}{l}0.01 \\
0.01 \\
0.04 \\
0.01\end{array}$ & $\begin{array}{l}0.69 \\
0.67 \\
0.76 \\
0.70\end{array}$ & $\begin{array}{l}0.57 \\
0.62 \\
0.58 \\
0.68\end{array}$ & $\begin{array}{l}0.01 \\
0.01 \\
0.01 \\
0.01\end{array}$ & $\begin{array}{l}0.23 \\
0.59 \\
0 \cdot 38 \\
0.05\end{array}$ & $\begin{array}{l}0 \cdot 10 \\
0 \cdot 37 \\
0 \cdot 25 \\
0 \cdot 06\end{array}$ & $\begin{array}{r}40 \cdot 50 \\
9 \cdot 20 \\
16 \cdot 80 \\
90 \cdot 20\end{array}$ & $\begin{array}{l}0 \cdot 80 \\
0 \cdot 73 \\
0 \cdot 63 \\
0.52\end{array}$ & $\begin{array}{l}0.70 \\
0.62 \\
0.38 \\
0.32\end{array}$ & $\begin{array}{r}0 \cdot 50 \\
3 \cdot 00 \\
3 \cdot 00 \\
12 \cdot 30\end{array}$ \\
\hline $\begin{array}{l}\log (C o-B) \\
\text { Monday endshift } \\
\text { ME-MM } \\
\text { Friday endshift } \\
\text { FE-FM }\end{array}$ & $\begin{array}{l}0.69 \\
0.77 \\
0.73 \\
0.55\end{array}$ & $\begin{array}{l}0.48 \\
0.48 \\
0.52 \\
0.37\end{array}$ & $\begin{array}{l}0.01 \\
0.01 \\
0.01 \\
0.05\end{array}$ & $\begin{array}{l}0.67 \\
0.35 \\
0.62 \\
0.43\end{array}$ & $\begin{array}{l}0 \cdot 39 \\
0 \cdot 25 \\
0 \cdot 38 \\
0 \cdot 34\end{array}$ & $\begin{array}{l}0.01 \\
7 \cdot 30 \\
0 \cdot 01 \\
2 \cdot 50\end{array}$ & $\begin{array}{r}0.12 \\
0.22 \\
0.35 \\
-0.44\end{array}$ & $\begin{array}{r}0.05 \\
0.19 \\
0.13 \\
-0.11\end{array}$ & $\begin{array}{l}68 \cdot 20 \\
72 \cdot 20 \\
20 \cdot 00 \\
45 \cdot 60\end{array}$ & $\begin{array}{l}z \\
z\end{array}$ & $\begin{array}{l}E \\
-\end{array}$ & $\begin{array}{l}E \\
-\end{array}$ \\
\hline
\end{tabular}

Co-air = TWA airborne cobalt concentration $\left(\mu \mathrm{g} / \mathrm{m}^{3}\right) ;$ Co-U = cobalt in urine $(\mu / \mathrm{g}$ creatinine); Co-B = cobalt in blood $(\mu \mathrm{g} / \mathrm{dl})$; ME-MM = difference (postshiftpreshift) on Monday; FE-FM = difference (postshift-preshift) on Friday; $r=$ Pearson correlation coefficient; $b=$ regression coefficient. 
metal group, both on Monday and Friday although the differences were not statistically significant.

The relations between cobalt concentration in the breathing zone (inhalable dust) and the concentration of cobalt in postshift urine and blood were examined on an individual basis. Table 2 presents the regression $(b)$ and correlation $(r)$ coefficients of these relations with their respective $p$ values (log scales). Good correlations were found for salt, metal, and hard metal workers. The correlations were not improved when only the increase in cobalt concentration over the shift period was taken into account (ME-MM and FE-FM, table 2). No major differences between the subclasses were found whatever blood or urine was considered. By contrast no significant correlation was found among the oxide workers, either for urine or for blood. When using a variable possibly related to cumulative exposure (product of Monday cobalt in air $\times$ duration of exposure in years) rather than recent exposure, the relation with urine and blood values were also non-significant in the oxide group $(r=0 \cdot 22$, $\mathrm{p}=0.43$ and $r=0.30, \mathrm{p}=0.29$, respectively).

Because the regression coefficients in the salt, metal, and hard metal groups were not significantly different, the results collected for those workers were pooled (figure). The relation between individual values of air and postshift urine cobalt concentrations measured on Friday was expressed by the equation:

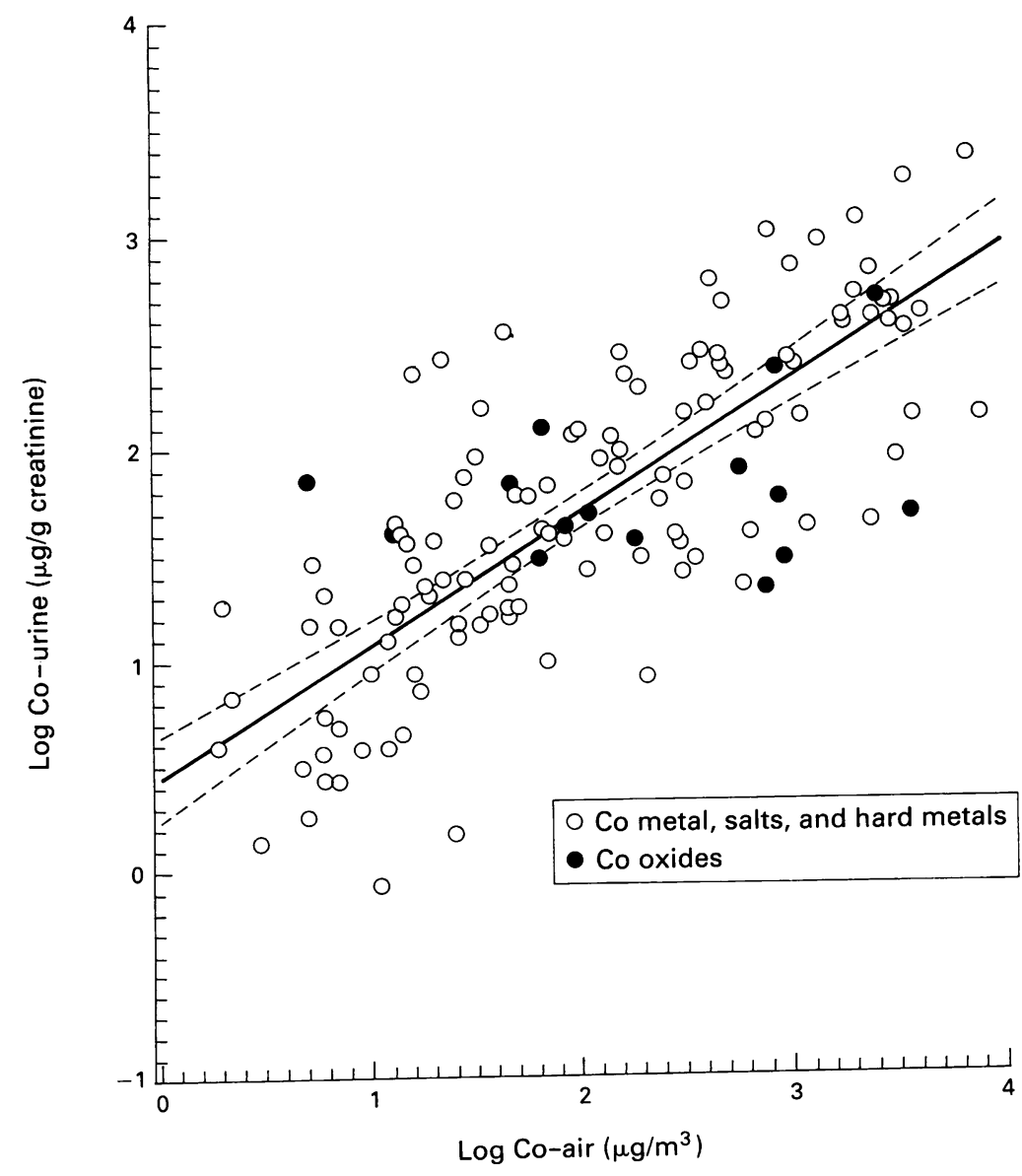

Relation between cobalt concentration (log scale) in air and in postshift urine samples collected at the end of the workweek (log scale). The interval between the dashed lines represents the $95 \%$ confidence interval around the regression line (solid line). $\log$ cobalt in urine $(\mu \mathrm{g} / \mathrm{g}$ creatinine $)=$

$0.44+0.63 \log$ cobalt in $\operatorname{air}\left(\mu \mathrm{g} / \mathrm{m}^{3}\right)$

As shown in the figure, the workers exposed to cobalt oxides did not show any significant relation between end of shift cobalt in urine and in air. Similar results were obtained with Monday samples (results not shown).

\section{Discussion}

In subjects occupationally exposed to cobalt the urinary excretion and the blood or serum concentration of the metal have been proposed as biological indicators of recent exposure. So far, however, most biological monitoring studies have been carried out with hard metal workers. In a study of 10 groups of such workers (range of cobalt in air 28-367 $\mu \mathrm{g} / \mathrm{m}^{3}$ ), Ichikawa $e t a^{7}$ found a good correlation between cobalt concentration in blood and cobalt in air on the basis of the mean values found in the different groups. For similar groups of workers, Pellet et $a l^{8}$ have suggested that the difference between end and beginning of shift urinary cobalt concentration reflected the daily exposure (range of cobalt in air $120-284 \mu \mathrm{g} / \mathrm{m}^{3}$ ), the concentration in the Friday evening urine was indicative of the cumulative exposure during the week and the concentration of cobalt in urine collected on Monday morning mainly reflected long term exposure. In another group of hard metal workers exposed to airborne concentrations below $100 \mu \mathrm{g} / \mathrm{m}^{3}$ there was an increase of urinary cobalt concentration as the workweek proceeded. ${ }^{3}$ In a study of diamond polishers using cobalt containing discs the measurement of urinary cobalt concentration, when considered on a workshop basis, reflected the amount of exposure (below $50 \mu \mathrm{g} / \mathrm{m}^{3}$ ). ${ }^{9}$

No comparative data are available for other forms of cobalt to which workers may be exposed. The absorption rates of such forms are, however, likely to be dependent on their solubility in biological media, which may also be influenced by the concomitant presence of other substances such as carbides. ${ }^{11} 12$

The importance of the chemical nature of the exposure has been pointed out by Christensen and Mikkelsen. ${ }^{13}$ These authors found increased concentrations of cobalt in blood $(0 \cdot 2-24 \mu \mathrm{g} / \mathrm{l})$ and urine $(0 \cdot 4-848 \mu \mathrm{g} / \mathrm{l})$ from pottery plate painters who used a soluble cobalt paint, whereas only slightly increased values were measured in those who used insoluble cobalt paint $(0.05-0.6 \mu \mathrm{g} / 1$ in blood and $0 \cdot 05-7 \cdot 7 \mu \mathrm{g} / 1$ in urine).

Our results confirm that urine and blood cobalt concentrations reflect recent exposure to cobalt metal, salt, and hard metal powders (soluble forms). This does not seem to apply, however, for exposure to cobalt oxide. Although concentrations of cobalt in blood and urine were higher than in non-exposed subjects, no relation between biological and environmental indices could be evidenced in the group of workers exposed to oxides. This cannot be simply explained by a difference in the size distribution of the airborne powders as the alveolar fraction was around $10 \%$ in the 
four groups. Therefore, we suggest that although significant absorption of cobalt may occur through dissolution of the oxide in alveolar macrophage lysosomes, ${ }^{14}$ its pulmonary absorption in humans might be lower than with soluble compounds. In hamsters intratracheally dosed with cobalt oxide, $60 \%$ of the dose was recovered in the gastrointestinal tract after 24 hours. The amount of cobalt recovered in the digestive tract was supposed to have been cleared from the lung because gastrointestinal secretion of cobalt is very low. In rats the pulmonary absorption of inhaled cobalt oxide is even less. ${ }^{1}$ Early experimental work by Delahant and Schepers also showed that cobalt oxide was less toxic to the lung than the metal form; these authors suggested that differences in solubilities might account for these different reactivities. ${ }^{15} 16$ The present finding of increased cobalt in blood and urine in oxide workers, unrelated to recent exposure, may therefore result from a delayed pulmonary absorption of the metal deposited in the lungs.

It has been shown in animal experiments that the pulmonary absorption of cobalt is greatly increased in the presence of tungsten carbide. ${ }^{17}$ In the present study, we found no evidence for this. One should however remain cautious in the interpretation of these results as exposure concentrations were notably low in the hard metal group and perhaps at higher ambient concentrations the absorption may be modified-for example, by the presence of inflammatory processes.

In conclusion, depending on the chemical form to which the workers were exposed, clear differences were found in the relations between air and urine or blood cobalt concentrations. Although biological monitoring of workers exposed to cobalt oxides showed greater blood and urine concentrations than in non-exposed subjects, these indices only poorly reflected the recent exposure level. By contrast, when exposure was to soluble cobalt compounds, the measurement of urinary or blood cobalt at the end of the workweek could be recommended for the monitoring of workers. An eight hour exposure to 20 or $50 \mu \mathrm{g} / \mathrm{m}^{3}$ of a soluble form of cobalt would lead to an average concentration (in a postshift urine sample collected at the end of the workweek) of 18.2 or $32.4 \mu \mathrm{g}$ of cobalt/g creatinine, respectively.

1 Elinder CG, Friberg L. Cobalt. In: Friberg L, Nordberg $\mathrm{G}$, Vouk V, eds. Handbook on the toxicology of metals. 2nd ed. Vol II. Amsterdam: Elsevier Science Publishers, 1986.

2 Kusaka Y, Kumagai S, Kyono H, Kohyama N, Shirakawa T. Determination of exposure to cobalt and nickel in the atmosphere in the

3 Scansetti G, Lamon S, Talarico S, Botta G, Spirelli P, Sulotto $F$ and Funtari $F$. Urinary cobalt as a measure of exposure in the hard metal industry. Int Arch Occup Environ Health 1985;57:19-26.

4 Ichikawa Y, Kusaka Y, Goto S. Biological monitoring of cobalt exposure, based on cobalt concentrations in blood and urine. Int Arch Occup Environ Health 1985;55: and urime.

5 Alexanderson R. Blood and urinary concentrations as estimators of cobalt exposure. Arch Environ Health 1988;43: 299.

6 Posma F, Dijstelberger S. Serum and urinary cobalt levels as indicators of cobalt exposure in hard metal workers. In: Lekkas S, ed. International conference "Heary metals in the environment". Athens: September, 1985:89.

7 Ichikawa Y, Kusaka Y, Ogawa Y, Shirikawa T, Fujimura $N$. Changes of cobalt concentrations in blood and urine. XXI International congress on occupational health. 27 September-2 October 1987, Sidney, Australia.

8 Pellet F, Perdrix A, Vincent M, Maillon JM. Dosage biologique du cobalt urinaire. Intérêt en médecine du travail dans la surveillance des expositions aux carbures métalliques frittés. Archives des Maladies Professionelles. 1984;45:81.

9 Nemery B, Casier P, Roosels D, Lahaye D, and Demedts $M$. Survey of cobalt exposure and respiratory health in diamond polishers. Am Rev Respir Dis 1992;145:610-6.

10 Swennen B, Buchet JP, Stanescu D, Lison D, Lauwerys R Epidemiological survey on workers exposed to cobalt oxides, cobalt salts, and cobalt metal. $\mathrm{Br} \mathcal{F}$ Ind Med 1993;50:835-42.

11 Lison $D$, Lauwerys $R$. In vitro cytotoxic effects of cobalt containing dusts on mouse peritoneal and rat alveolar macrophages. Environ Res 1990;52:187-98.

12 Lison D, Lauwerys R. Study of the mechanism responsible for the elective toxicity of tungsten carbide-cobalt powfor toward macrophages. Toxicol Lett 1992;60:203-10.

13 Christensen JM, Mikkelsen S. Cobalt concentration in whole blood and urine from pottery plate painters exposed to cobalt paint. In: Lekkas S, ed. International conference "Heavy metals in the environment". Vol 2. Athens:September, 1985:86.

14 Kreyling WG, Godleski J, Kariya ST, Rose RM, Brain $\mathrm{JD}$. In vitro dissolution of uniform cobalt oxide particles by human and canine alveolar macrophages. Am $\mathcal{F}$ Respir Cell Mol Biol 1990;2:413-22.

15 Schepers G. The biological action of particulate cobalt metal. Archives of Industrial Health 1955;12:127-33.

16 Delahant AB. Experimental study of the effecs of rare metals on animal lungs. Archives of Industrial Health metals on animal

17 Lasfargues G, Lison D, Maldague P, Lauwerys $R$. Comparative study of the acute lung toxicity of pure cobalt powder and cobalt-tungsten carbide mixture in the rat. Toxicol Appl Pharmacol 1992;112:41-50. 